\title{
PROSES PEMBELAJARAN MATEMATIKA PADA ANAK SLOW LEARNERS (LAMBAN BELAJAR)
}

\author{
Fida Rahmantika Hadi \\ fidarahmantika88@ikippgrimadiun \\ FIP IKIP PGRI MADIUN
}

\begin{abstract}
This research is aimed to find out the mathematics learning process in class includes readiness of teacher before learning process, implementation and evaluation and follow up. It was a qualitative research. The subjects were taken by purposive sampling. The subjects of this research were mathematics teacher. Data collection techniques in this research were interviews and observation. Technical validity of the data used is triangulation time. The data analysis technique used was consisted of data reduction, data display, and conclusion. The results of this study were (1) teacher preparedness before learning process are by preparing syllabus, lesson plan (RPP), media and learning resources before the learning process begins. (2) the mathematics learning implementation in class done through three activities: pre activity, whilst activity and post activity (3) in evaluation and follow-up stage, teachers plan follow-up activities in the form of remedial learning, enrichment programs, counseling services for students (4) Factors and constraints experienced from slow learners child is may lose interest in the task and refused to resume the task. Keyword: mathematic learning process, slow learner child
\end{abstract}

\begin{abstract}
Abstrak
Penelitian ini bertujuan untuk mengetahui proses pembelajaran matematika di kelas meliputi kesiapan guru sebelum proses pembelajaran, perencanaan, pelaksanaan serta evaluasi dan tindak lanjut. Penelitian ini merupakan penelitian kualitatif. Subyek diambil secara purposive sampling. Subyek dalam penelitian ini adalah guru matematika. Teknik pengumpulan data dalam penelitian ini adalah wawancara dan observasi. Teknik validitas data yang digunakan adalah triangulasi waktu. Teknik analisis data yang digunakan terdiri dari reduksi data, penyajian data, dan kesimpulan. Hasil penelitian ini antara lain (1) kesiapan guru sebelum proses pembelajaran dimulai yaitu menyiapkan silabus, rencana pelaksanaan pembelajaran (RPP), media dan sumber belajar, (2) pelaksanaan pembelajaran matematika di kelas melalui tiga tahapan kegiatan yaitu tahap pendahuluan, tahap inti pembelajaran dan tahap penutup (3) dalam tahap evaluasi dan tindak lanjut, guru merencanakan kegiatan tindak lanjut dalam bentuk pembelajaran remedi, program pengayaan, layanan konseling untuk siswa (4) Faktor atau kendala yang dialami slow learners adalah dapat kehilangan ketertarikan terhadap tugas yang diberikan oleh guru dan menolak untuk melanjutkan mengerjakan tugas ketika mereka bosan.

Kata kunci: proses pembelajaran matematika, siswa lamban belajar
\end{abstract}




\section{A. PENDAHULUAN}

Anak-anak memiliki tingkat yang berbeda-beda dalam belajar. Salah jika menempatkan mereka pada satu anggapan bahwa semua anak sama karena mereka memiliki tingkat pemahaman yang berbeda dengan anak lain, baik akademis atau yang lainnya. Griffin (dalam Younis, 2008) menyatakan bahwa pada dasarnya slow learnes atau lamban belajar adalah siswa yang memilikikesulitan bersaing dengan teman sekelas mereka. Lamban belajar tidak mengalami keterbelakangan mental, namun mampu mencapai keberhasilan akademis pada tingkat lebih lambat dibandingkan dengan siswa kelas normal atau biasa (Singh dalam Pujar. 2006).

Anak lamban belajar (slow learner) merupakan anak yang memiliki potensi intelektual sedikit di bawah normal, tetapi tidak termasuk anak tuna grahita. Slow learner secara akademis biasanya diidentifikasi berdasarkan skor yang dicapai mereka pada tes kecerdasan, dengan IQ antara 70-89 (Malik, 2012). Anak slow learner ini mengalami hambatan atau keterlambatan berpikir dalam beberapa hal, merespon rangsangan dan beradaptasi, tetapi lebih baik dibanding dengan tunagrahita, lebih lamban dari normal. Di sisi lain Tim Pengembang Ilmu Pendidikan FIPUPI (2011) menyatakan bahwa slow learner juga mempunyai nilai pelajaran sangat rendah yang ditandai pula dengan tes IQ berada di bawah rata-rata anak pada umumnya.

Slow learner saat di dalam kelas membutuhkan waktu belajar lebih lama dibanding dengan sebayanya. Kecerdasan mereka memang di bawah rata-rata, tetapi mereka bukan anak yang tidak mampu, tetapi mereka butuh perjuangan yang keras untuk menguasai apa yang diminta di kelas regular (Ratna dan Dany, 2011). Anak yang demikian akan mengalami hambatan belajar, sehingga prestasi belajarnya biasanya juga di bawah prestasi belajar anak-anak normal lainnya, yang sebaya dengannya Geniofam (2010) menyatakan bahwa anak slow learner ini memiliki apa yang disebut dengan hambatan belajar dan hambatan perkembangan (barrier to learning and development). Borah (2013) juga menjelaskan mengenai hambatan atau 
kelemahan akademik utama yang dialami oleh slow learner adalah membaca, berbahasa, memori, sosial, dan perilaku.

Salah satu kelemahan dalam proses belajar siswa slow learner pada pelajaran matematika, biasanya pada pelajaran ini prestasi belajarnya kurang. Pelajaran matematika dikategorikan sebagai pelajaran yang tidak disukai sebagian siswa. Ketidaksenangan siswa pada pelajaran ini dapat berpengaruh pada keberhasilan belajar siswa. Keberhasilan belajar siswa tidak hanya dipengaruhi dari faktor siswa saja, melainkan juga dari faktor guru. Oleh karena itu sudah semestinya guru sebagai pendidik khususnya bidang studi matematika dapat menghilangkan anggapan-anggapan siswa yang kurang baik terhadap pembelajaran matematika, sehingga proses pembelajaran dapat berjalan dengan baik.

Siswa slow learner
dimungkinkan akan mengalami
berbagai macam kendala selama
proses pembelajaran berlangsung.
Oleh karena itu sebagai guru
matematika yang harus dapat

memberikan penyelesaian terhadap kendala-kendala yang dialami siswa tersebut agar tidak ditemukan lagi saat proses pembelajaran selanjutnya. Kendala-kendala yang terjadi harus dapat ditangani dengan cepat agar siswa slow learner dapat mengikuti pembelajaran matematika bersama siswa lainnya dan mencapai hasil yang optimal dalam pembelajarannya.

Dari uraian tersebut mendorong peneliti untuk mengetahui bagaimana proses pembelajaran matematika di kelas yang meliputi kesiapan guru sebelum proses pembelajaran, perencanaan, pelaksanaan dan evaluasi dan tindak lanjut? Apakah yang menjadi faktor atau kendala yang dialami siswa slow learners saat proses pembelajaran matematika di kelas?

\section{B. METODE PENELITIAN}

Penelitian ini dilakukan untuk mendiskripsikan proses pembelajaran matematika pada anak slow learner (lamban belajar). Subjek dalam penelitian ini adalah guru matematika. Data utama penelitian ini berupa informasi tentang proses pembelajaran matematika yang 
meliputi perencanaan pembelajaran, pelaksanaan pembelajaran, evaluasi dan tindak lanjut. Data tersebut diperoleh dari wawancara dan observasi. Wawancara dilakukan sebanyak dua kali. Metode observasi yang digunakan dalam penelitian ini adalah metode observasi pasif yaitu peneliti hanya mengamati proses pembelajaran yang dilakukan guru menggunakan lembar observasi. Observasi dilakukan sebanyak dua kali.

Teknik analisis data yang digunakan adalah reduksi data, penyajian data, dan penarikan kesimpulan. Validasi data menggunakan triangulasi waktu, yaitu dengan menyocokkan hasil observasi dan hasil wawancara pertama dengan hasil observasi dan hasil wawancara kedua sehingga dari hasil rekaman tersebut diperoleh transkrip kegiatan pembelajaran matematika.

\section{HASIL PENELITIAN DAN PEMBAHASAN}

Berkaitan dengan proses pembelajaran matematika di kelas, kesiapan guru sangat diperlukan sebelum dimulainya pembelajaran yaitu menyiapkan rencana pelaksanaan pembelajaran (RPP). Menurut Moh. Uzer Usman (2001) dalam membuat rencana pembelajaran/satuan acara pembelajaran, seorang guru harus memperhatikan beberapa hal yang sangat menentukan keberhasilan proses belajar mengajar yang sesuai dengan RPP. Di SDN Taman 3, sebelum pembelajaran dimulai guru matematika menyiapkan RPP dan silabus. Sebelum proses pembelajaran berlangsung guru matematika telah menyusun RPP dan silabus. Penyusunan RPP biasanya dilakukan setelah selesai satu kompetensi dasar. Kesiapan lainnya yang dilakukan guru matematika yaitu menyiapkan media dan sumber belajar. Media yang biasa digunakan disesuaikan dengan materi apa yang akan dijelaskan sedangkan sumber belajar yang digunakan yaitu buku paket. Pelaksanaan pembelajaran matematika di kelas melalui tiga tahap, yaitu pendahuluan, inti dan penutup. Proses pembelajaran yang berlangsung sudah sejalan dengan langkah-langkah kegiatan 
pembelajaran menurut Depdiknas (2008). Dalam pelaksanaan pembelajaran tahap pendahuluan, guru matematika menyiapkan siswa secara psikis dan fisik sebelum proses pembelajaran. Guru matematika juga menyiapkan psikis dan fisik siswa, menjelaskan tujuan pembelajaran dan kompetensi dasar yang akan dicapai sebelum menjelaskan materi yang diajarkan.

Guru matematika memberikan pertanyaan pengetahuan yang berkaitan dengan materi yang akan dibahas pada tahap pendahuluan. Siswa slow learner diberikan pertanyaan yang lebih mudah dari siswa lain. Siswa slow learner lebih diperhatikan oleh guru matematika ketika mengikuti pembelajaran di kelas. Dalam tahap inti pembelajaran yang dilakukan guru matematika menggunakan beragam pendekatan pembelajaran, media pembelajaran dan sumber belajar lain. Dalam pelaksanaan pembelajaran guru matematika melibatkan siswa secara aktif dalam setiap kegiatan pembelajaran dengan memberikan soal-kerjakan-jawab yang membuat siswa berani berbicara untuk menjawab. Guru matematika selalu membantu atau memotivasi agar siswa slow learner tersebut berani menjawab di kelas. Guru matematika memfasilitasi terjadinya interaksi antara siswa dengan siswa slow learner, antara siswa dengan guru dalam setiap pembelajaran dengan tidak membedakan antara siswa maupun slow learner.

Dalam proses pembelajaran guru matematika selalu memantau dan membimbing slow learner. Guru matematika pada tahap penutup bersama siswa membuat rangkuman atau kesimpulan pelajaran yang melibatkan siswa. Siswa slow learner dalam membuat rangkuman selalu dibantu dan dibimbing oleh guru matematika. Guru matematika melakukan penilaian untuk siswa setelah selesai membuat rangkuman. Guru matematika memberikan umpan balik terhadap proses dan hasil pembelajaran dengan memberikan pertanyaan-pertanyaan mengenai materi yang telah diajarkan.

Proses

pembelajaran matematika yang dilaksanakan pada tahap terakhir adalah evaluasi dan tindak lanjut. Dalam tahap ini guru 
matematika merencanakan kegiatan tindak lanjut dalam bentuk pembelajaran remedi, program pengayaan, layanan konseling untuk siswa yang mengalami kesulitan. Muhibbin Syah (2003) menyatakan bahwa evaluasi adalah penilaian terhadap tingkat keberhasilan siswa mencapai tujuan yang telah ditetapkan dalam sebuah program. Tingkat keberhasilan siswa dilihat dari pencapaian standart KKM. Guru matematika juga selalu menyampaikan rencana pembelajaran yang akan dilaksanakan untuk pertemuan berikutnya.

Faktor-faktor kesulitan atau kendala dapat dialami siswa slow learner saat proses pembelajaran matematika berlangsung. Kendala yang mereka alami yaitu dapat kehilangan ketertarikan terhadap tugas yang diberikan oleh guru matematika. Mereka juga menolak untuk melanjutkan tugas ketika mereka bosan. Mereka merasa senang atau semangat saat diberi tugas namun dapat juga secara tiba-tiba mereka malas karena bosan (mood berubah-ubah). Chauhan (2011) menyatakan bahwa salah satu karakteristik siswa slow learners adalah memori atau daya ingatnya rendah dan kurangnya konsentrasi. Guru matematika harus mempunyai penyelesaian untuk kendala-kendala yang dialami siswa slow learner agar tidak ditemukan lagi saat proses pembelajaran selanjutnya.

\section{SIMPULAN DAN SARAN}

Berdasarkan hasil penelitian dan pembahasan dapat disimpulkan sebagai berikut. (1) Kesiapan guru matematika sebelum proses pembelajaran dimulai yaitu menyiapkan RPP, silabus, media dan sumber belajar. (2) Pelaksanaan pembelajaran matematika di kelas melalui tiga tahap, yaitu pendahuluan, inti dan penutup. (3) Dalam tahap evaluasi dan tindak lanjut, guru merencanakan kegiatan tindak lanjut dalam bentuk pembelajaran remedi, program pengayaan, layanan konseling untuk siswa yang mengalami kesulitan. (4) Faktor atau kendala yang dialami siswa slow learner adalah dapat kehilangan ketertarikan terhadap tugas tersebut dan menolak untuk melanjutkan pekerjaan tugas (mood berubahubah). 
Berdasarkan simpulan penelitian di atas, dapat disampaikan saran sebagai berikut. Guru perlu mempersiapkan dengan baik sebelum proses pembelajaran berlangsung agar pelaksanaan pembelajaran dapat berjalan baik pula. Guru harus mengajak semua siswa termasuk siswa slow learner untuk berpartisipasi aktif dalam pembelajaran matematika antara lain dengan selalu memotivasi siswa terutama siswaslow learners sehingga mempunyai semangat tinggi dalam belajar.

\section{DAFTAR PUSTAKA}

Borah, R. R. 2013. Slow Learners: Role of Teachers and Guardians inHoning their Hidden Skills. International Journal of Educational Planning \& Administration. 3(2), 139-143.

Chauhan, S. 2011. Slow Learners: Their Psychology and Educational Programmes. International Journal of Multidisciplinary Research, 1(8), 279-289.

Depdiknas. 2008. Policy Brief, Sekolah Inklusif; Membangun Pendidikan Tanpa Diskriminasi. Jakarta: Pusat Kurikulum, Balitbang Depdiknas.
Geniofam. 2010. Mengasuh dan Mensukseskan Anak Berkebutuhan Khusus. Jogjakarta: Garailmu.

Malik, N. I, Rehman, G. Hanif, R. 2012. Effect of Academic Interventions on theDevelopmental Skills of Slow Learners. Pakistan Journal of Psychological Research, 27(1), 135-151.

Moh. Uzer Usman. 2001. Menjadi Guru Profesional. Bandung: Remaja Rosdakarya.

Muhibbin Syah. 2003. Psikologi Pendidikan dengan Pendekatan Baru. Bandung: PT. Remaja Rosdakarya. Undang-Undang Nomor 20 tahun 2003 tentang Sistem Pendidikan Nasional.

Pujar, L. L. 2006. Instructional Strategies To AccelerateScience Learning Among Slow Learners. Tesis Magister, tidak diterbitkan. University Of Agricultural Sciences, Dharwad. Diambil Pada 31 Januari 2014 dari http://etd.uasd.edu/abst/th8596. pdf.

Ratna Yudhawati \& Dhany Haryanto. 2011. Teori-teori Dasar Psikologi Pendidikan. Jakarta: Prestasi Pustaka.

Younis S. A, Batinah S. R. 2008. Slow Learners: How are they Identified and Supported?. International Journal, 1, 166172. 